\title{
Changing Museum Visitors' Conceptions of Evolution
}

\author{
Amy N. Spiegel • E. Margaret Evans • Brandy Frazier • \\ Ashley Hazel • Medha Tare • Wendy Gram • \\ Judy Diamond
}

Published online: 12 April 2012

(C) Springer Science+Business Media, LLC 2012 also increased their use of one intuitive reasoning pattern, need-based (goal-directed) explanations, which, we argue, may be a step toward evolutionary reasoning. Nonetheless, visitors continued to use mixed reasoning (endorsing all three reasoning patterns) in explaining biological change. The personal, socio-cultural, and contextual variables were found to be related to these reasoning patterns in predictable ways. These findings are used to examine the structure of visitors' reasoning patterns and those aspects of the exhibition that may have contributed to the gains in museum visitors' understanding of evolution.

Keywords Museum visitors · Free-choice learning · Developmental model $\cdot$ Evolutionary reasoning $\cdot$ Exhibition

An understanding of evolution is a fundamental component of a broader goal, that of scientific literacy (National

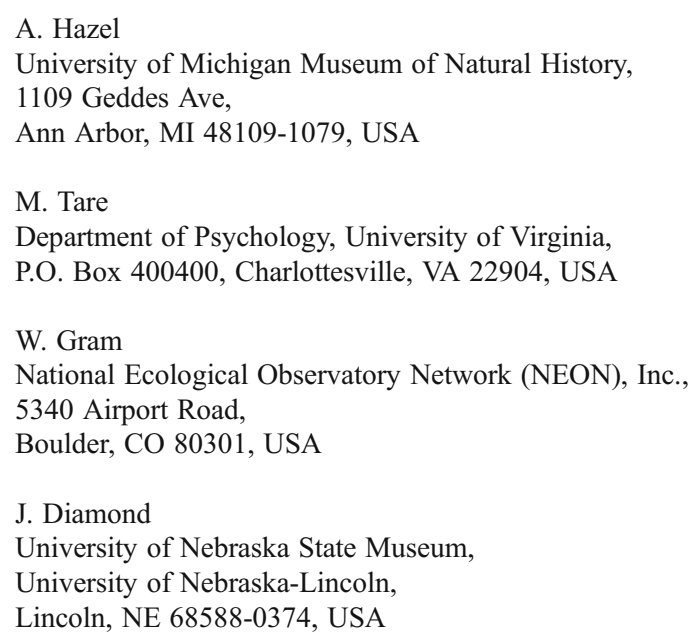


Research Council 1996; American Association for the Advancement of Science 1994). Many scientific investigations that affect our everyday lives utilize evolutionary reasoning, including research on cancer and HIV, the recently rapid evolution of antibiotic-resistant bacteria, and the impact of climate change. Yet many U.S. adults have little or no understanding of the mechanisms of evolutionary change (National Science Board 2012), and almost half of them do not accept evolutionary origins (Miller 2001). Moreover, a significant proportion of our public schools fail to include, limit content, or obscure instruction on evolutionary theory (Catley 2006; Lerner 2000 ), with up to $20 \%$ of high school biology teachers including intelligent design or creationism as part of the science curriculum (Moore and Kraemer 2005). As many as 33\% of high school biology teachers are unsure of or do not accept evolution as a scientifically valid explanation for the state of living organisms (Rutledge and Mitchell 2002).

To move toward the goal of scientific literacy for its citizens, the U.S. must enhance and expand ways to include evolution in the educational system. New science discoveries and continually changing technology mean that scientific literacy involves learning across a lifetime (Miller 2001). In addition to formal educational settings, informal or free-choice educational opportunities should be considered as part of the science education framework (Bybee 2001; St. John and Perry 1993). Free-choice learning environments play a significant role in teaching the public about evolution (Diamond and Scotchmoor 2006; Spiegel et al. 2006), with one third of U.S. citizens reporting visiting a museum and $61 \%$ visiting some type of informal science venue in the past year (D'Elia and Jörgensen 2003; National Science Board 2012). Increasing the overlap among museums, science centers, media outlets, and other informal learning sites with school-based education can increase the depth and breadth of an individual's science knowledge (Bybee 2001; Ramey-Gassert et al. 1994).

Evolution is a critical science topic taught in both formal and informal environments, and understanding how learning takes place in both contexts can help guide future efforts to improve the public's understanding of science. While students' understanding of evolution topics in schools has been the subject of considerable study (e.g., Banet and Ayuso 2003; Bishop and Anderson 1990; Brumby 1979; Greene 1990; Gregory 2009; Jiménez-Aleixandre 1994; Passmore and Stewart 2002; Trowbridge and Wandersee 1994), how free-choice learning about evolution takes place in informal environments remains an open question. Our focus, therefore, is on adult and child museum visitors and the kinds of changes that occur in their understanding of evolution when they are exposed to an interactive exhibition on evolution. To frame this study, we integrate a developmental model of the general public's understanding of evolution, developed in earlier research (Evans 2000, 2001, 2008; Evans, et al. 2010), with a model of free-choice learning.

\section{Conceptual Framework: Museum Visitors' Understanding of Evolution}

Free-choice learning, which takes place in environments such as museums or science centers, differs from formal learning in that it is "self-directed, voluntary, and guided by individual needs and interests" (Falk and Dierking 2002, p. 9). Formal education, in contrast, has a given format, particular prerequisites, obligations, and constraints. Educators working in environments designed for free-choice learning have recently begun more rigorous work to examine and understand the learning that occurs in these settings. In the last decade, theoretical models on learning in museums have incorporated personal, contextual, and sociocultural variables to provide a framework within which to investigate and interpret learning in free-choice environments (Bell et al. 2009; Vadeboncoeur 2006). Moreover, there is evidence to indicate that science learning in museums is mediated by these identified variables (Adelman et al. 2000; Anderson et al. 2000; Bamberger and Tal 2007; Falk and Storksdieck 2005; Falk and Adelman 2003). A recent review of museum visitor studies on the topic of evolution, however, has found that most have not been framed theoretically but instead focused on elements such as visitor interest, visitor understanding of terms, and visitor acceptance of evolutionary concepts (Spiegel et al. 2006). These studies revealed that museum visitors are more accepting of evolution than is the general public (People for the American Way 2000; Stein and Storksdieck 2005) and are also more accepting of non-human evolution than human evolution (Hayward et al. 1996; Pawlukiewicz et al. 1990; Spiegel et al. 2006). In addition, these studies identified a high level of visitor interest in evolution topics (Borun 2002; Stein and Storksdieck 2005). However, visitor understanding of terms was limited and frequently contained misinformation indicating use of alternative conceptions (Borun 2002; MacFadden et al. 2007; People, Places, and Design Research 1992; Squire and Hubbell Mackinney 1996).

The current study of visitor learning at an evolution exhibition is informed by a theoretical framework that includes elements of the free-choice learning models integrated within a constructivist model that incorporates the intuitive beliefs that visitors bring to the learning process (Evans 2008; Evans, et al. 2010). While lack of acceptance of evolution stems in part from strongly held religious beliefs (Evans 2008; Mazur 2005; Numbers 1992), lack of understanding may also be explained by the intuitive reasoning processes that both children and adults use to make sense of everyday biological events (Evans 2000, 2001; Gregory 2009; Sinatra et al. 2008). In the current paper, we argue that one reason that evolutionary concepts are so difficult to learn is because of initial cognitive biases that 
appear early in childhood and that continue to exert their influence on adult reasoning (Bloom and Weisberg 2007; Evans 2000, 2001, 2008; Evans et al. 2010). These earlyemerging intuitive reasoning patterns include the essentialist intuition that species are unique and stable, as well as the intuition that any changes within species are goal directed and intentional (Keil 1994; Kelemen 1999; Gelman 2003; Mayr 1982; Medin and Atran 2004; Wellman and Gelman 1998). Evolutionary explanations are counterintuitive, probably more so than most complex scientific explanations, because they challenge this commonsense understanding of the natural world (Evans 2000, 2001, 2008; Sinatra et al. 2008). Natural phenomena, including living things, constantly change and, further, this change is neither purposeful nor directed toward a specific end-point.

In the conceptual model that we are utilizing, these intuitive reasoning processes provide the foundation for reasoning about evolutionary problems. Over time, these intuitions become interconnected with the system of beliefs, practices, and values that comprise the socio-cultural practices that are part of everyday experiences (Evans 2000, 2001). This process shapes the beliefs that visitors bring to an exhibition on evolution. In the U.S., in particular, individuals are influenced by two potentially divergent cultural frameworks: Christian fundamentalist creationist beliefs that may support or even extend these intuitive reasoning patterns; and scientific models, which typically do not (Evans 2008; Evans et al. 2010). Our theoretical model includes the intuitive beliefs of the museum visitor, the belief systems to which the visitor subscribes, the visitor's personal interests, and the particular context of the museum exhibition in the current study: "Explore Evolution."

\section{Explore Evolution Exhibition Description}

"Explore Evolution" is an exhibition project funded by the National Science Foundation to increase public understanding of evolution (Diamond and Evans 2007; Diamond et al. 2012). It included the development of a permanent exhibit gallery, copies of which are currently installed at five museums across the Midwest. Illustrating the mechanisms of evolution as well as descriptions of phylogenetic change, the exhibition focuses on seven current research projects in evolutionary science. These include work on the rapid evolution of HIV, the fossil record of the emergence of a new diatom species, farming ants and their coevolving partners, sexual selection in Hawaiian flies, changes in Galápagos finch populations, genetic links between humans and chimps, and the fossil discovery of walking whales. In contrast to most natural history museum exhibitions, "Explore Evolution" illustrates contemporary research on evolution across diverse organisms, ranging from the microscopic to the largest of all mammals, using interactive, hands-on exhibits that portray the activities and laboratory or field settings of each of the featured scientists (see Fig. 1 for an example). The exhibition links these diverse studies by emphasizing the interaction of four fundamental evolutionary principles: variation, inheritance, selection, and time (VIST).

The VIST conceptual framework (used with permission from the University of California Museum of Paleontology) served as a unifying theme throughout the exhibition, with specific information about how variation, inheritance, selection, and time all play a role in the evolution of each organism (see Fig. 2 for an example). Variation refers to the genetic differences among individuals in a population; inheritance describes the process by which traits are passed from parents to offspring; selection is the process through which those organisms with traits that are adaptive in their particular environment are more likely to live long enough to have offspring; and time is the idea that evolution requires successive generations before changes in a population can be observed. The VIST framework is a cognitive organizer designed to help visitors generalize these evolutionary principles across the diverse organisms in the exhibition.

\section{The Current Study: Prior Research and Research Predictions}

The current study was designed to assess the extent to which the "Explore Evolution" exhibition contributes to conceptual change (Carey 1985; Sinatra et al. 2008; Vosniadou 2008) in visitors' reasoning about evolution. In previous research (Evans 2005; Evans et al. 2010) prior to the installation of the "Explore Evolution" exhibition, adult museum visitors were presented with scenarios describing changes in the seven organisms presented in the exhibition. Visitors were asked open-ended questions about how these changes

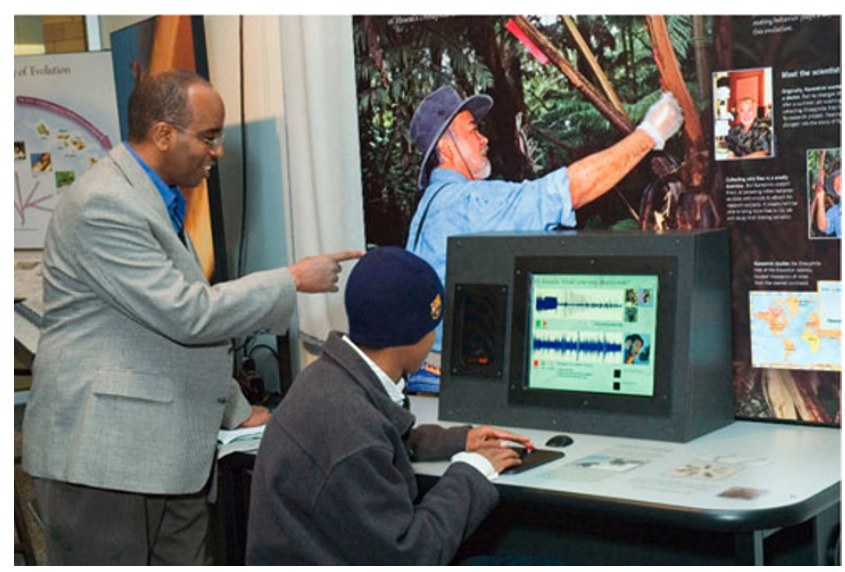

Fig. 1 Two visitors at the "Explore Evolution" exhibition fly unit, which includes an interactive screen and a background photo of the scientist working in the field 


\section{Making New Species with Love Songs}

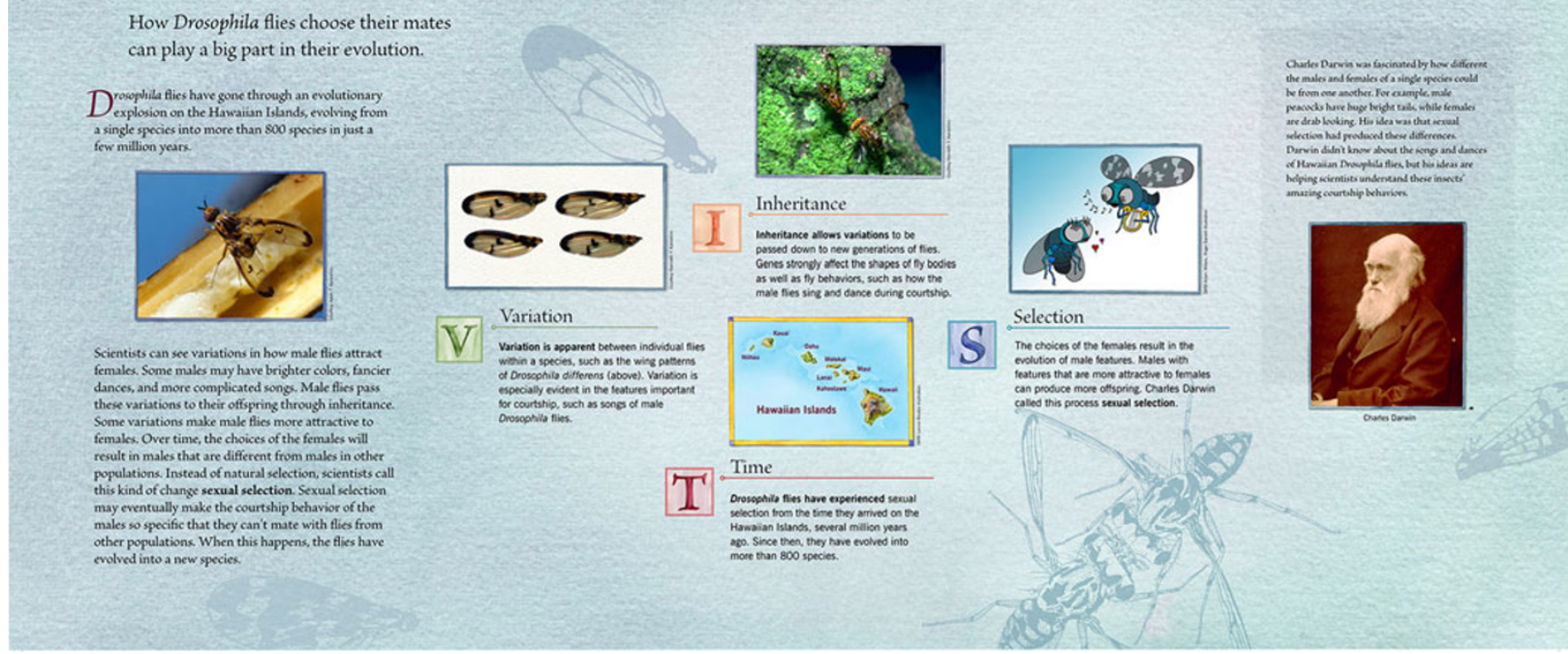

Fig. 2 The "Explore Evolution" exhibition VIST panel for the fly unit

occurred. The interviewers refrained from mentioning evolution as a possible mechanism. For example, participants were told that the first few fruit flies arrived on the Hawaiian Islands several million years ago and now there are 800 different species, and then asked explain how this happened. The explanations given by the museum visitors in their responses to each of the seven evolutionary problems were transcribed and coded. Of particular interest was whether museum visitors would spontaneously invoke evolutionary ideas. Responses that included themes from the intuitive reasoning patterns, described earlier, were categorized as intuitive or novice naturalistic reasoning; responses that included themes from the Darwinian model (such as the VIST Framework) were categorized as evolutionary or informed naturalistic reasoning; whereas those that expressed supernatural concepts were categorized as using creationist reasoning.

In this initial study, it was found that even in a sample of well-educated museum-going adults, not one visitor invoked the evolutionary reasoning pattern for all seven organisms, and overall, just over a third of the sample $(38 \%)$ demonstrated a reasonable grasp of evolutionary concepts. All of the participants combined intuitive and evolutionary reasoning patterns, while a minority also used creationist reasoning. Mammals and birds were more likely than microorganisms or invertebrate species to invoke the evolutionary reasoning pattern. Twenty-eight percent endorsed creationist explanations for human origins, although only six percent were consistently creationist across all seven organisms.
This foundational study provided evidence for the argument that intuitive cognitive biases found in early childhood persist in adulthood, even in well-educated populations interested enough in natural history to visit museums. An example of an essentialist bias was found in the refusal to acknowledge that biological change of this magnitude occurred: New species could not have emerged from ancestral forms (Evans et al. 2010). Reminiscent of similar explanations found in children's responses (Evans 2000, 2001), some adults would use what is called proximate-cause reasoning, proposing instead that the apparently new organism had always existed and could be found someplace else.

In the same study, a distinction was drawn between two kinds of goal-directed or teleological explanations (Evans 2000; Southerland et al. 2001): (1) desire- or want-based explanations, which imply that the organism has free will and can intentionally change its body parts to adapt to the environment, such as, "the animal changes because it wants (desires) to," and (2) need-based explanations: "the animal changes because it needs to." The latter may cite or implicate an animal's intrinsic needs - that the changes are deemed necessary for survival-without referencing conscious mental states such as desire (Evans et al. 2010). The results of the latter study suggested that the ability to disassociate need-based from desire-based reasoning is an important step, with need-based reasoning providing a foundation for an initial grasp of evolutionary reasoning. Younger elementary school children are more likely than older children to use desire-based explanations of evolutionary 
change (Evans 2000). In contrast, adults are more likely to use need-based explanations (Evans et al. 2010). Typically, individuals who endorse either of these explanations describe species change in terms of individual change (Bishop and Anderson 1990). The rabbit, for example, acquires white fur because it needs to or wants to hide from predators, subsequently passing on this acquired trait to future generations. Pre-existing variability within species is ignored. In this way, the essentialist intuition that each kind (or species) has an immutable essence is maintained. In contrast, Darwinian evolutionary concepts challenge these intuitions: species are ever-changing, and while those changes are sometimes adaptive, they are not directed toward the goal of surviving in a particular environment.

In the current study, the research questions focused on how museum visitors might change their reasoning patterns as a result of a naturalistic visit to the "Explore Evolution" exhibition. Although museum-goers are less likely to be creationist than the population at large (Spiegel et al. 2006), they are not, as described above, well informed about evolution (Evans et al. 2010; Macfadden et al. 2007). As such, they provide a useful population to assess which aspects of evolutionary thinking, if any, are absorbed in a single visit to an evolution exhibition. The current focus, therefore, is on measuring incremental change in visitors' reasoning patterns.

As well as examining change in the use of evolutionary explanations, we were particularly interested in whether exposure to the exhibit would result in a decrease of one or both intuitive explanations: need-based and desire-based reasoning. This study uniquely assessed this relationship using closed-ended questions, providing a more accurate measure of change than can be obtained with open-ended questions, such as those used in the earlier study (Evans et al. 2010). This measure gave visitors the opportunity to endorse one or both explanations independently of each other, which permits a more nuanced analysis of their relationship. If, as suggested by the earlier pattern of findings as well more recent work with younger children (Legare et al. 2012), need-based (but not want-based) reasoning acts as a "bridge" to evolutionary understanding (Evans et al. 2010, p. 348), then it should be positively associated with evolutionary reasoning and either remain stable or increase from pre- to post-assessment. In addition, we examined the differences between child and adult reasoning patterns and the relationship among the socio-cultural, personal, and contextual variables included in the study. Three instruments were used: (1) a closed-ended questionnaire based on themes that emerged in an analysis of the open-ended questions in the earlier study, described above (2) a subset of items from the earlier open-ended instrument, and (3) measures of visitors' beliefs, personal and demographic variables, and time spent at and interest in the exhibition.
Based on the earlier study (Evans et al. 2010) we expected to find that most museum visitors' explanations of evolutionary processes would comprise a mixture of different reasoning patterns. In particular, we predicted that as a function of exposure to the exhibition (1) use of the evolutionary reasoning pattern would increase. Furthermore, we predicted (2) a disassociation between the three intuitive explanations, with desire-based and proximate cause, but not need-based (goal-directed) reasoning, decreasing. In addition, we predicted (3) that visitors' beliefs, in particular, whether they endorsed a creationist or an evolutionist perspective, would influence their receptivity to the exhibition material, with creationist reasoners being the least likely to change. Finally, we predicted (4) that the age of the visitor would influence receptivity to the materials, with child visitors being more likely to endorse intuitive and creationist reasoning patterns and older visitors more likely to endorse evolutionary reasoning patterns.

\section{Methods}

\section{Participants}

Participants were recruited by e-mail through the membership rosters of two Midwest natural history museums and a local children's zoo, and offered $\$ 20$ as compensation for the time spent on the study. Only volunteers who had not yet seen the exhibition were included in the sample, which was stratified to obtain approximately half youth respondents and half adult respondents, split by gender. Other than these criteria, visitors were randomly selected and scheduled to visit the museum exhibit and participate in the study. Each participant was independent and was not related to (in the same family unit as) any other participant. The instruments and all procedures were approved prior to use by the participating universities' Institutional Review Boards. All participants gave their informed consent prior to their participation, which included audio-taping of the openended questions.

Sixty-four visitors (50\% female and 50\% male; $91 \%$ nonHispanic white, six percent Asian American, and three percent other ethnicity) participated. Just over half the sample were children (11-13 years, $n=21,33 \%)$ and youth (1418 years, $n=13,20 \%)$. The remaining participants were adults ( 19 years and older, $n=30,47 \%$ ). The education level of the adult participants was high (ten percent some college, $43 \%$ 4-year college, and 47\% graduate courses). Similarly, the children and youth participating had highly educated parents (six percent some college, $21 \%$ college graduates, and $68 \%$ graduate courses). A high percentage of visitors with college education or more is typical of science centers and natural history museums (Korn 1995; Smithsonian 
Institution 2006, 2010). Only one adult participant, a biology lab technician, indicated a biology background. The median number of museum visits in the last year reported by participants was three (range was 0-20).

\section{Procedure}

The study began with a pre-visit questionnaire, a closedended instrument with four evolution scenarios based on four of the seven organisms featured in the exhibition (finch, virus, ant/fungus, and human/chimp) (see Table 1, for a summary). Visitors were then asked to visit the exhibition and spend as much or as little time as they liked, and to spend time as they would during a "normal museum visit." Every visitor in our study (except for two, who viewed the exhibit together), viewed the exhibition alone. The length of the visits ranged from eight to 100 minutes $(M=34, \mathrm{SD}=$ 20 ). When they finished their visit to the gallery, participants were asked three open-ended interview questions about the remaining three organisms featured in the exhibition: fly, diatom, and whale. They were then asked to complete the full seven-organism, post-visit closed-ended questionnaire. Finally, participants were asked to complete a questionnaire that included demographic, socio-cultural, and contextual measures.

\section{Instruments}

Open-ended Post-visit Interview Questions The three interview questions in the current study were taken from the open-ended instrument used in an earlier study (Evans et al. 2010), which examined the reasoning of natural history museum visitors who were not told that the scenarios were about evolution. Each evolutionary scenario focused on one of the core research questions addressed by the scientists featured in the exhibition. Only three of the seven organisms in the exhibition were included in the openended questions in the current interview because of the design of the pre- and post-visit questionnaires (see below). The fly, diatom, and whale were chosen because they represented a range in size of organism and also a range in familiarity (Evans et al. 2010). Visitors' responses to these three open-ended questions will be compared with the quantitative results and also used to examine developmental differences.

Closed-ended Questionnaire Development The questionnaire was based directly on the open-ended interview instrument described above (Evans et al. 2010), using virtually the same questions, but in a closed-ended format (see Appendix A for list of questions). Each of the seven evolutionary scenarios used in the questionnaire focused on a different organism or pair of organisms (whale, human/chimp, finch, fly, ant/fungus, diatom, and virus) with a picture of the organisms. Visitors were asked to rate their level of agreement with each of seven explanations for each problem, presented in a randomized order across scenarios. The explanations themselves and the language used in the explanations were both derived from the most prevalent themes in visitors' responses to the earlier open-ended questions (Evans et al. 2010) and the kind of language visitors in that study used to explain the problems (see Tables 2 and 3 for definitions and examples). Of the seven explanations, three focused on evolutionary reasoning (evolution term,

Table 1 Instruments used in the study

\begin{tabular}{|c|c|c|c|c|}
\hline When used & Instrument & Description & Organisms included & Scoring/coding used \\
\hline $\begin{array}{l}\text { Before gallery } \\
\text { visit }\end{array}$ & Pre-visit questionnaire & $\begin{array}{l}\text { Closed-ended instrument with } \\
4 \text { evolution scenarios, each } \\
\text { with } 7 \text { different explanations } \\
\text { to rate }\end{array}$ & $\begin{array}{l}\text { Virus, ant/fungus, finch, and } \\
\text { human/chimp }\end{array}$ & $\begin{array}{l}\text { Summated scaled scores for each } \\
\text { type of explanation were } \\
\text { calculated across organisms }\end{array}$ \\
\hline $\begin{array}{l}\text { After gallery } \\
\text { visit }\end{array}$ & Interview & $\begin{array}{l}\text { Open-ended interview with } \\
3 \text { evolution scenarios }\end{array}$ & Diatom, fly, and whale & $\begin{array}{l}\text { Specific themes within each } \\
\text { reasoning pattern were coded } \\
\text { as present or absent }\end{array}$ \\
\hline $\begin{array}{l}\text { After gallery } \\
\text { visit }\end{array}$ & $\begin{array}{l}\text { Post-visit } \\
\text { questionnaire }\end{array}$ & $\begin{array}{l}\text { Closed-ended instrument } \\
\text { with } 7 \text { evolution scenarios, } \\
\text { each with } 7 \text { different } \\
\text { explanations to rate }\end{array}$ & $\begin{array}{l}\text { Virus, diatom, ant/fungus, fly } \\
\text { finch, human/chimp, and whale }\end{array}$ & $\begin{array}{l}\text { Summated scaled scores for each } \\
\text { type of explanation were } \\
\text { calculated across organisms }\end{array}$ \\
\hline $\begin{array}{l}\text { After gallery } \\
\text { visit }\end{array}$ & $\begin{array}{l}\text { Demographic, } \\
\text { sociocultural, and } \\
\text { contextual measure }\end{array}$ & $\begin{array}{l}\text { Likert, short-answer, and } \\
\text { ratings items on sociocultural, } \\
\text { personal, and contextual } \\
\text { variables, including age, } \\
\text { gender, museum visitation, } \\
\text { education level, science } \\
\text { community variables, religious } \\
\text { community variables, and } \\
\text { interest level in organisms }\end{array}$ & $\begin{array}{l}\text { N/A except for ratings and } \\
\text { rankings of interest level in } \\
\text { virus, diatom, ant/fungus, fly, } \\
\text { finch, human/chimp, and whale }\end{array}$ & $\begin{array}{l}\text { For multi-item variables, summated } \\
\text { scaled scores were calculated; for } \\
\text { single-item variables, the } \\
\text { simple-scale score was used }\end{array}$ \\
\hline
\end{tabular}


Table 2 Evolutionary reasoning pattern: themes, definitions, and examples

Table 3 Intuitive reasoning pattern: themes, definitions, and examples

\begin{tabular}{|c|c|c|}
\hline Theme & Operational definition & Examples - current study \\
\hline Evolution term & Mention of evolution terms & $\begin{array}{l}\text { Evolved, Darwin(ian), survival of the fittest, } \\
\text { and common ancestor }\end{array}$ \\
\hline VIST term & Mention of VIST terms & Variation, inheritance, selection, and time \\
\hline Variation & $\begin{array}{l}\text { Differences among individuals } \\
\text { in a population }\end{array}$ & $\begin{array}{l}\text {... a variant of the pre-existing algae; a } \\
\text { sort-of-genetic uniqueness to the different } \\
\text { fly variations }\end{array}$ \\
\hline Inheritance & $\begin{array}{l}\text { Traits (genes) are inherited and } \\
\text { passed on to the next generation }\end{array}$ & $\begin{array}{l}\text { (Diatom) so it simply carried on those traits as } \\
\text { it split off or reproduced }\end{array}$ \\
\hline $\begin{array}{r}\text { Common } \\
\text { descent }\end{array}$ & $\begin{array}{l}\text { Reference to common ancestors } \\
\text { (implication that they were a } \\
\text { different species) }\end{array}$ & $\begin{array}{l}\ldots \text { the original algae were a type found in many } \\
\text { other lakes ...; it came from one fly; ... originally } \\
\text { the whale derived from a land animal or mammal }\end{array}$ \\
\hline $\begin{array}{l}\text { (Natural) } \\
\text { selection }\end{array}$ & $\begin{array}{l}\text { Organisms with adaptive traits } \\
\text { are more likely to survive }\end{array}$ & $\begin{array}{l}\text { (Whale) ... because of the features that were } \\
\text { selected that favored their ability to live on land } \\
\ldots \text { those diatoms that had offspring that had } \\
\text { characteristics that were more adapted to the } \\
\text { new environment were more successful than } \\
\text { those who did not }\end{array}$ \\
\hline Time & $\begin{array}{l}\text { There had to be enough time for } \\
\text { Natural selection to occur }\end{array}$ & $\begin{array}{l}\text { When you think of something happening over } \\
\text { tens of millions of years, it's kind of } \\
\text { mind-boggling; ... it changed over time }\end{array}$ \\
\hline $\begin{array}{l}\text { Sexual } \\
\text { Selection }\end{array}$ & Any reference to sexual selection & $\begin{array}{l}\text { The male flies evolved to have those things on } \\
\text { their legs; (fly) some of the characteristics } \\
\text { would have appealed to the girls }\end{array}$ \\
\hline $\begin{array}{c}\text { Ecological } \\
\text { pressure }\end{array}$ & $\begin{array}{l}\text { Mention of ecological pressures } \\
\text { as a causal agent in } \\
\text { diversification or change }\end{array}$ & $\begin{array}{l}\text {... the algae responded to various climate } \\
\text { changes; (fly) ... because they were on } \\
\text { different islands ... the foods ... the weather } \\
\text { and stuff ... }\end{array}$ \\
\hline
\end{tabular}

\begin{tabular}{|c|c|c|}
\hline Theme & Operational definition & Examples-current study \\
\hline $\begin{array}{l}\text { Desire-based } \\
\text { change }\end{array}$ & $\begin{array}{l}\text { Use of mental states, skills or conscious } \\
\text { effort to explain change }\end{array}$ & $\begin{array}{l}\text { (Whale/hippo) some of the relatives } \\
\text { discovered that they could subsist better in } \\
\text { water; One decides it likes the water and } \\
\text { the other one decides it likes the land }\end{array}$ \\
\hline $\begin{array}{l}\text { Static } \\
\text { adaptation }\end{array}$ & $\begin{array}{l}\text { References the organism-environment fit } \\
\text { as the reason why a particular organism } \\
\text { might be found in a particular location or } \\
\text { have particular features }\end{array}$ & $\begin{array}{l}\text { Hippos actually sleep in the water; } \\
\text { (whale/hippo) the ones that were in the } \\
\text { water, they had different ways of } \\
\text { breathing than the animals on land }\end{array}$ \\
\hline $\begin{array}{l}\text { Adaptive } \\
\text { feature list }\end{array}$ & $\begin{array}{l}\text { Simply lists adaptive features of } 1 \text { or } \\
\text { more organisms }\end{array}$ & $\begin{array}{l}\text { (Whale/hippo) ... its skull structure is } \\
\text { different, its mouth is wide, and its nostrils } \\
\text { are further forward and it has tusks }\end{array}$ \\
\hline $\begin{array}{l}\text { Goal-directed } \\
\text { adaptation }\end{array}$ & $\begin{array}{l}\text { (1) The organism changes to meet a need } \\
\text { or purpose, a functional or adaptive goal- } \\
\text { directed behavior } \\
\text { (2) The organism develops towards an } \\
\text { inbuilt goal [no mention of need] }\end{array}$ & $\begin{array}{l}\text { (Fly)... for their ability to survive, they } \\
\text { needed longer wings or something; } \\
\text { (whale/hippo) some of the animals moved } \\
\text { onto land and they needed longer legs; ... } \\
\text { (diatom) gradual evolution into a more } \\
\text { complicated life form }\end{array}$ \\
\hline \multirow[t]{2}{*}{$\begin{array}{l}\text { Proximate } \\
\text { cause }\end{array}$} & $\begin{array}{l}\text { (1) An agent brought the organism in } \\
\text { from some place else }\end{array}$ & $\begin{array}{l}\text { (Flies) certainly, the winds bring some things, } \\
\text { well maybe like an animal brought it there }\end{array}$ \\
\hline & $\begin{array}{l}\text { (2) The organism was always there, but } \\
\text { was not detected }\end{array}$ & $\begin{array}{l}\text { Well, your premise is faulty because how do } \\
\text { you know there weren't any [flies] that } \\
\text { long ago? }\end{array}$ \\
\hline Reproduction & $\begin{array}{l}\text { Reference to reproduction, no clear } \\
\text { reference to inherited features }\end{array}$ & $\begin{array}{l}\text { (Flies) they kept mating; [Diatoms] } \\
\text { apparently reproduce just by splitting; }\end{array}$ \\
\hline Hybridization & 2 unrelated animals interbred & $\begin{array}{l}\text { Different } \ldots \text { diatoms } \ldots \text { mingled } \ldots \text { and } \\
\text { produced the } \ldots \text { species }\end{array}$ \\
\hline
\end{tabular}


natural selection, and common descent) and three on intuitive reasoning (need-based adaptation, desire-based change, and proximate cause). The final explanation reflected one type of creationist reasoning (intentional design) (see Table 4, for an example, for the fly).

Because visitors' reasoning in the earlier study was often found to be mixed (including two or more themes from different reasoning patterns), the items in this questionnaire were designed so that respondents could choose to agree or disagree with each explanation, independently of the others (see Table 4; Appendix A). The survey instrument was reviewed by biologists, museum educators, and cognitive psychologists, and piloted on a sample of adults and youth before final revisions were made.

Closed-ended Instrument: Pre- and Post-visit Visitors used a five-point Likert scale to rate their level of agreement with each of the seven explanations for each of the seven scenarios (49 rating items altogether). For each explanation, we created an explanation measure by combining the same explanation items across all seven organisms. For example, the means of the evolution term explanation item for all seven organisms were averaged to create a composite variable called evolution term. Summating the items to create scales provides a more reliable and valid way to measure the constructs than a single item; and parametric statistics, which we use with the rating scale data, have been shown to be robust and appropriate for this application (Norman 2010). Cronbach's alphas were calculated for each of the seven measures on the post-test. Overall alphas were between 0.80 and 0.95 , and all individual items within the explanation measures were identified as contributing to the scales. Generally, a reliability coefficient of 0.70 is considered acceptable (Nunnally 1978). Each of these seven summated rating scales was measured independently of each other, hence every participant had seven unique scores, one for each type of explanation, representing the extent that explanation was endorsed across the seven evolution scenarios.

A subset of the full questionnaire, consisting of the questions for four (finch, virus, ants/fungus, and human/ chimp) of the seven organisms, was used as the pre-visit closed-ended questionnaire (see Table 1). This was done to minimize the total time that participants spent on the study and to avoid alerting the participants to our interest in all of the organisms. In addition to reducing potential priming effects, this design also enabled a pre-post analysis across the four organisms used in the closed-ended questions from the post-visit questionnaire, which included all the organisms (see Table 1). In the post-visit questionnaire, all seven question sets were presented in a fixed order (the human/ chimp question was last), with the four pre-visit question sets intermixed with the three sets not included in the pretest. Using a closed-ended pre- and post-design combined with a small number of open-ended items limited

Table 4 Closed-ended instrument: explanations and examples of items

Type of reasoning Specific explanation Operational definition pattern
Example of explanation (Fly question: "at one time there were no fruit flies on the Hawaiian Islands. Scientists think that several million years ago, a few fruit flies came to the islands. Now there are more than 800 different kinds of fruit flies throughout Hawaii. How would you explain these observations?")

\begin{tabular}{|c|c|c|c|}
\hline $\begin{array}{l}\text { Evolutionary } \\
\text { reasoning }(\mathrm{ER})\end{array}$ & Evolution term & Uses the term "evolution" & The different kinds of flies are the result of evolution \\
\hline ER & Natural selection & $\begin{array}{l}\text { Organisms with adaptive traits are } \\
\text { more likely to survive }\end{array}$ & $\begin{array}{l}\text { Some flies mutated and were better able to live on the } \\
\text { Hawaiian Islands, so those flies had more offspring than } \\
\text { the others }\end{array}$ \\
\hline ER & Common descent & $\begin{array}{l}\text { Recognition of a common ancestor } \\
\text { (implication that this was a different } \\
\text { species) }\end{array}$ & $\begin{array}{l}\text { The new kinds of fruit flies came from the first fruit flies } \\
\text { on the Hawaiian Islands }\end{array}$ \\
\hline $\begin{array}{l}\text { Intuitive reasoning } \\
\text { (IR) }\end{array}$ & $\begin{array}{l}\text { Need-based } \\
\text { adaptation }\end{array}$ & $\begin{array}{l}\text { The organism changes to meet a need } \\
\text { or purpose; a functional or adaptive } \\
\text { goal-directed behavior }\end{array}$ & $\begin{array}{l}\text { The first fruit flies needed to change into different kinds in } \\
\text { order to live on the different Hawaiian islands }\end{array}$ \\
\hline IR & Desire-based change & $\begin{array}{l}\text { Use of mental states, skills or } \\
\text { conscious effort to explain change }\end{array}$ & $\begin{array}{l}\text { The first fruit flies wanted to change so they could live on } \\
\text { the different Hawaiian Islands }\end{array}$ \\
\hline IR & Proximate cause & $\begin{array}{l}\text { The new organism has always been in } \\
\text { existence; either undetected or } \\
\text { brought from somewhere else }\end{array}$ & The different kinds of fruit flies came from other places \\
\hline Creationist reasoning & Intentional design & Each organism was created specially ${ }^{\mathrm{a}}$ & Special fruit flies were created to live on Hawaii \\
\hline
\end{tabular}

${ }^{\mathrm{a}}$ To develop a questionnaire that could be used with populations from diverse religious backgrounds and ages, the word God was not included, even though participants in the original study had done so (Evans et al. 2010) 
pretest priming effects and still provided qualitative data with additional, descriptive information.

Demographics, Beliefs, Sociocultural, and Personal Variables: Post-visit The post-visit measures included demographic variables, such as age, education level and occupation, and Likert scale measures of visitors' beliefs. For the religious community, these were: (1) religiosity (how important is religion in your life?) and (2) compatibility of the participant's religion with evolution. For the science community, these were: (1) acceptance of evolutionary origins for three types of organisms: insects, birds, and humans (three items averaged into a composite scale; Cronbach's alpha $=0.91$ ), and (2) importance of scientists' studying evolution.

In addition, personal variables included: (1) self-assessed knowledge of evolution, and (2) the importance of one's own understanding of evolution. Finally, contextual variables relating to the museum visit itself included two measures of engagement: (1) interest level in the different organisms at the exhibition (composite scale of ratings) and (2) number of minutes spent at the exhibition. Given the controversial nature of the exhibition, we wanted to avoid potentially intrusive visitor tracking measures, and we also reasoned that these measures of engagement would be a good proxy for any tracking measures.

Qualitative Coding Summary: HIV, Fly, and Whale Responses to the open-ended interview questions on the three organisms (HIV, fly, and whale) were recorded and transcribed. The coding and content analyses used for the interview responses were those used in the prior study (see Evans et al. 2010 for details). Coding of the conceptual units within each response was based on a coding scheme comprised of three reasoning patterns discussed earlier: evolutionary reasoning (ER), intuitive reasoning (IR), and creationist reasoning (CR). As was done in the earlier study, for each response to each question, specific themes within these reasoning patterns were coded as present (1) or absent (0). Participants' responses for each organism were coded individually by experienced raters, with $75 \%$ of the responses coded by two raters. Initial inter-rater reliability was $93 \%$, and following resolution of discrepancies, the final inter-rater reliability was $100 \%$.

\section{Results}

This section will be presented in three sections: (1) closedended questionnaire data: pre- to post-visit changes, (2) qualitative interview data: post-visit, and (3) relationships between socio-cultural variables and endorsement of the three reasoning patterns.
Closed-ended Questionnaire: Pre-Visit to Post-Visit Change for Four Organisms

Virus, Finch, Ant/Fungus, and Human/Chimp: Overview of Analyses We examined the changes in the summated scale explanation measures from pre-visit to post-visit for the four organisms (virus, finch, ant, and human) included in both questionnaires. As explained earlier, the design of the closed-ended questionnaire resulted in separate summated scale scores for each of the seven explanations. In the analyses, we first conducted one-tailed $t$ tests to examine whether there were significant differences in the predicted direction, pre-visit to post-visit, for each of the explanation measures in the overall sample. To examine the role of age in these changes, participants were grouped into three age categories and $t$ tests conducted for each age group separately.

Pre- to Post-visit Change The overall pre-visit to post-visit changes across the sample in the seven explanation measures are presented in Table 5. Significant change was found for all three ER explanations (evolutionary term; common descent, and selection). To examine these changes more closely, the sample was broken down into three agegroups: children (11-13 years), youth (14-18 years), and adults (19 years and older). The youngest group is similar to age ranges previously studied in other investigations of evolutionary concepts, while the middle group is most likely to have been exposed to evolutionary ideas at school (Evans 2001, 2005). While results from these smaller sample sizes must be interpreted with caution, they inform the nature of the change occurring across the sample. All significant changes in ER scores were in the predicted direction, indicating that all three age groups increased their use of evolutionary reasoning. The scaled scores for the IR explanations were mixed. Endorsement of need-based adaptation explanations increased significantly for the group as a whole and for the adults, and endorsement of desire-based change decreased overall and for the adults. The $C R$ intentional design explanations showed a trend toward a decline, but these changes were not statistically significant.

Another way to examine this change is to calculate the percentage of visitors who had changes in their scale scores. For the ER explanations, $91 \%$ of visitors increased on at least one type of ER scale. Of those nine percent who did not increase their ER scores, nearly all were already endorsing ER explanations at almost maximal levels, creating a ceiling effect. In contrast, the ten percent of visitors who exhibited the most positive change in their ER explanation scores (change group) were those whose ER explanation pre-test scores were significantly lower than average $(F=12.2, p<0.001)$. For the IR explanations, half of the visitors decreased their use of desire-based and proximate 
Table 5 Explaining evolutionary change: pre- and post-visit means and change scores across four organisms on closed-ended questionnaire for adult, youth, and child museum visitors
$E R$ evolutionary reasoning,

$I R$ intuitive reasoning,

$C R$ creationist reasoning

${ }^{*} p \leq 0.05 ; * * p<0.01$;

$* * * p<0.001$

\begin{tabular}{|c|c|c|c|c|}
\hline Explanation & Overall sample $(N=64)$ & $\begin{array}{l}\text { Children }(n=21) \\
11-13 \text { years }\end{array}$ & $\begin{array}{l}\text { Youth }(n=13) \\
14-18 \text { years }\end{array}$ & $\begin{array}{l}\text { Adults }(n=30) \\
19+\text { years }\end{array}$ \\
\hline \multicolumn{5}{|c|}{ ER - evolutionary term (mean (SD)) } \\
\hline Pre-visit & $4.15(0.89)$ & $3.92(0.86)$ & $4.23(1.12)$ & $4.28(0.80)$ \\
\hline Post-visit & $4.39(0.94)$ & $4.13(1.00)$ & $4.42(1.09)$ & $4.55(0.82)$ \\
\hline Change score & $0.23 * * *(0.55)$ & $0.21(0.79)$ & $0.19 *(0.27)$ & $0.27 * *(0.44)$ \\
\hline \multicolumn{5}{|c|}{ ER—common descent (mean (SD)) } \\
\hline Pre-visit & $4.08(0.71)$ & $4.02(0.70)$ & $4.19(0.68)$ & $4.08(0.74)$ \\
\hline Post-visit & $4.46(0.66)$ & $4.45(0.54)$ & $4.42(0.67)$ & $4.49(0.75)$ \\
\hline Change score & $0.38 * * *(0.50)$ & $0.43 * *(0.58)$ & $0.23 *(0.33)$ & $0.42 * * *(0.50)$ \\
\hline \multicolumn{5}{|c|}{ ER — selection (mean (SD)) } \\
\hline Pre-visit & $4.15(0.71)$ & $3.75(0.57)$ & $4.46(0.54)$ & $4.29(0.75)$ \\
\hline Post-visit & $4.47(0.63)$ & $4.25(0.72)$ & $4.52(0.59)$ & $4.60(0.56)$ \\
\hline Change score & $0.32 * * *(0.50)$ & $0.50 * * *(0.60)$ & $0.06(0.36)$ & $0.31 * * *(0.44)$ \\
\hline \multicolumn{5}{|c|}{ IR - need-based adaptation (mean (SD)) } \\
\hline Pre-visit & $4.27(0.61)$ & $4.23(0.68)$ & $4.50(0.41)$ & $4.21(0.63)$ \\
\hline Post-visit & $4.39(0.72)$ & $4.24(0.78)$ & $4.56(0.46)$ & $4.42(0.76)$ \\
\hline Change score & $0.11 *(0.44)$ & $0.01(0.41)$ & $0.06(0.21)$ & $0.21 *(0.52)$ \\
\hline \multicolumn{5}{|c|}{ IR - desire-based change (mean (SD)) } \\
\hline Pre-visit mean & $2.91(1.17)$ & $3.23(0.87)$ & $3.12(1.22)$ & $2.61(1.29)$ \\
\hline Post-visit & $2.71(1.26)$ & $3.18(1.20)$ & $2.96(1.27)$ & $2.28(1.20)$ \\
\hline Change-score & $-0.20 *(0.96)$ & $-0.05(0.96)$ & $-0.15(0.77)$ & $-0.33 *(1.03)$ \\
\hline \multicolumn{5}{|c|}{ IR - proximate cause (mean (SD)) } \\
\hline Pre-visit & $1.97(0.69)$ & $2.07(0.80)$ & $2.04(0.80)$ & $1.88(0.56)$ \\
\hline Post-visit & $1.89(0.87)$ & $2.24(1.07)$ & $1.81(0.87)$ & $1.68(0.64)$ \\
\hline Change score & $-0.09(0.57)$ & $0.17(0.57)$ & $-0.23(0.54)$ & $-0.20 *(0.54)$ \\
\hline \multicolumn{5}{|c|}{$\mathrm{CR}$ —intentional design (mean (SD)) } \\
\hline Pre-visit & $2.42(1.04)$ & $2.95(0.92)$ & $2.33(1.23)$ & $2.09(0.92)$ \\
\hline Post-visit & $2.32(1.14)$ & $2.94(0.96)$ & $2.13(1.14)$ & $1.96(1.11)$ \\
\hline Change score & $-0.11(0.66)$ & $-0.01(0.58)$ & $-0.19(0.49)$ & $-0.13(0.77)$ \\
\hline
\end{tabular}

cause explanations, but $45 \%$ increased endorsement of needbased adaptation. Creationist scores decreased for $45 \%$ of visitors.

Open-ended Interview Questions: Post-visit Pattern of Explanations for Three Organisms

Analyzing and coding the three open-ended interview questions yielded qualitative data on the percentage of identified themes from each of the three reasoning patterns present in respondents' explanations. These were examined across age groups to investigate developmental differences. We focused on the ER and IR patterns; coding for creationist reasoning will only be briefly reported, in part because we did not include an explicit creationist (God did it) explanation in the closed-ended questionnaire; therefore, there is no basis for comparison across the two kinds of measures. Furthermore, in the earlier study (Evans et al. 2010), creationist reasoning occurred mostly (28\%) for the openended question on human/chimp evolution, which was not included in the present study. Consistent with the earlier study, however, six percent of the visitors utilized creationist reasoning for the whale and the fruit fly questions.

Table 6 shows the percentage of respondents by age group who mentioned the different themes from the evolutionary and intuitive reasoning patterns for at least one organism. Across all the evolutionary reasoning pattern themes (see Table 2 for themes and examples), the child group had consistently lower percentages than either of the older groups. Use of an evolution term, the concepts of inheritance, common descent, and selection were all used by a greater proportion of both youth and adults than children. The concept of variation was used most frequently by the youth group, although a majority of respondents in all groups mentioned this ER theme. With respect to IR (see Table 3 for themes and examples), results were mixed, again providing converging evidence to support the findings from 
Table 6 Percentage of study respondents by age group mentioning identified themes within the evolutionary and intuitive reasoning patterns in their open-ended explanations

\begin{tabular}{lrcc}
\hline & $\begin{array}{l}\text { Child } \\
n=21(\%)\end{array}$ & $\begin{array}{l}\text { Youth } \\
n=13(\%)\end{array}$ & $\begin{array}{l}\text { Adult } \\
n=30(\%)\end{array}$ \\
\hline $\begin{array}{l}\text { Evolutionary reasoning themes } \\
\text { Evolution term }\end{array}$ & 48 & 92 & 90 \\
VIST term & 0 & 23 & 40 \\
Variation & 62 & 85 & 67 \\
Inheritance & 5 & 31 & 33 \\
Common descent & 19 & 62 & 67 \\
Selection & 19 & 54 & 60 \\
Time & 38 & 46 & 63 \\
Sexual selection & 10 & 15 & 40 \\
Ecological pressure & 48 & 62 & 80 \\
Intuitive reasoning themes & & & \\
Desire based & 24 & 0 & 30 \\
Static adaptation & 86 & 85 & 87 \\
Adaptive features list & 67 & 54 & 73 \\
Goal-directed adaptation & 43 & 69 & 43 \\
Proximate cause & 67 & 62 & 60 \\
Reproduction & 57 & 31 & 33 \\
Hybridization & 33 & 15 & 3 \\
\hline
\end{tabular}

the quantitative study (see Table 6). Static adaptation, the simple listing of adaptive features, and proximate causes were themes mentioned by a majority of respondents in all age groups. Reproduction and hybridization were mentioned most frequently by the child group. Desire-based reasoning was not mentioned by a single youth, although about one quarter of both children and adults used this intuitive reasoning theme. The youth also differed from the other groups in their use of goal-directed adaptation, in which over two thirds of youth mentioned this theme while only $43 \%$ of children and adults did.

\section{Relationships Between Sociocultural Variables and Endorsement of the Three Reasoning Patterns}

Overview In addition to gathering demographic data, our measures also included sociocultural variables concerning participants' beliefs about and attitudes toward science and religion. We first examined how participants responded to each of these measures, then we evaluated the intercorrelations between the measures. Finally, we investigated the extent to which these sociocultural variables related to visitors' reasoning patterns. Pearson's correlational coefficient $r$ was used in the analyses with the summated scaled scores of the different explanations and sociocultural variables, including age, which was measured as a continuous variable. For comparisons with ordinal data, Spearman's rho was used.
Relationship among the Sociocultural, Personal, and Contextual Variables The compatibility of religion with evolution variable was significantly positively related to the community of science variables, importance of self understanding evolution variable, and interest in the organisms at the exhibition (see Table 7). The two community of science variables were also significantly positively correlated with one another and with the importance of participants themselves understanding evolution. The personal/motivational variables were positively correlated with one another and with the two exhibition engagement variables.

Intercorrelations Among Post-visit Measures: Closed-Ended Questionnaire To examine the conceptual structure underlying visitors' reasoning patterns, analyses of visitors' postvisit scores on all seven organisms were conducted. Overall, visitors were much more likely to endorse the three ER explanations and the IR explanation of need-based adaptation than any of the other explanations (see Table 8, for means and standard deviations).

The pattern of intercorrelations among explanations revealed clusters of highly correlated explanations, which, we argue, correspond to distinct conceptual structures within each of the different reasoning patterns (see Table 8). The three ER explanations were all positively correlated with one another. Of the three IR explanations, only desire-based change and proximate cause were positively related to each other. However, there was no correlation between desirebased change and need-based adaptation. A negative correlation was found between proximate cause and need-based adaptation. Need-based adaptation (IR) was, however, positively correlated with all three ER explanations while proximate cause (IR) was negatively related to all three ER explanations. Desire-based change (IR) was not related to any ER explanation. The CR explanation was significantly negatively correlated with all three ER explanations and positively correlated with two of the IR explanations, desire-based change and proximate cause, but not with need-based adaptation.

Visitors who agreed with the evolutionary reasoning explanations had some understanding of evolutionary processes. However, this understanding did not mean that they necessarily rejected intuitive explanations. Only one third of those who "strongly agreed" with ER explanations disagreed or strongly disagreed with IR explanations, again demonstrating the tenacity of intuitive reasoning explanations. To investigate whether there were any visitors who did not exhibit mixed reasoning patterns, we tried to identify visitors who strongly agreed with all the evolutionary reasoning explanations while strongly disagreeing with the intuitive and creationist explanations. Not one visitor did so. 
Post-visit Reasoning Patterns and the Sociocultural, Personal, and Contextual Variables The earlier analyses indicate that regardless of background, the majority of visitors increased their use of evolutionary reasoning post-visit. In the current analysis, the relationship between the sociocultural, personal and contextual variables and visitors' overall reasoning patterns post-visit should give some insight into the impact of variables that were derived from the free-choice learning model incorporated into this study (see Table 9).

The religiosity variable was negatively correlated with endorsement of the evolution term. The compatibility of one's religion and evolution variable was positively correlated with all three ER explanations and negatively correlated with endorsement of the creationist variable. In contrast, the two community of science variables and the personal-motivational variables were positively related to the ER variables and negatively related to the IR proximate cause explanation and the $\mathrm{CR}$ intentional design explanation. Of the contextual variables, time spent at the exhibition was negatively correlated with IR proximate cause and CR intentional design. Age of participant was also negatively correlated with intentional design. This pattern of endorsement strongly indicates that our measures had robust construct and content validities.

We compared the nine percent of visitors who did not exhibit changes in their use of ER on the pre- versus postvisit questionnaire (no-change group) with the ten percent who exhibited the greatest increase in ER (change group). As described earlier, the no-change group was almost at ceiling on their ER ratings on the pre-visit questionnaire. Compared with the no-change group, those who increased their use of ER explanations had significantly higher ratings on religiosity $(F(1,10)=5.87, p<0.05)$ and significantly lower ratings on the importance of scientists' studying evolution $(F(1,10)=5.00, p<0.05)$ and on interest in the organisms $(F(1,10)=13.16, p<0.01)$.

Post-test Measures by Age Group Because of the prior research indicating developmental changes in reasoning about evolution (Evans 2000, 2001, 2008), means on the seven different reasoning patterns explanations were compared across three age groups: child, youth and adult. Means varied by age with some significant differences found between the child and adult groups. Children were significantly more likely to endorse the IR explanations of proximate cause $F(2,61)=4.68, p<0.05$ and desire-based change $F(2,61)=3.97, p<0.05$, as well as the CR explanation of intentional design $F(2,61)=5.61, p<0.01$. Children were also significantly less likely to endorse the ER explanation of selection $F(2,61)=3.29, p<0.05$. The youth group means typically fell between the children's and adults'. 
Table 8 Means and intercorrelations among post-exhibit closed-ended explanations

\begin{tabular}{llllllll}
\hline Mean (SD) & $\begin{array}{l}\text { ER-evolution } \\
\text { term }(4.45(0.91))\end{array}$ & $\begin{array}{l}\text { ER-common } \\
\text { descent } \\
(4.47(0.61))\end{array}$ & $\begin{array}{llll}\text { ER-selection } \\
(4.47(0.63))\end{array}$ & $\begin{array}{l}\text { IR-need } \\
(4.34(0.70))\end{array}$ & $\begin{array}{l}\text { IR-desire } \\
(2.63(1.17))\end{array}$ & $\begin{array}{l}\text { IR-proximate } \\
\text { cause } \\
(1.97(0.84))\end{array}$ & $\begin{array}{l}\text { CR-intentional } \\
\text { design }\end{array}$ \\
& & & & & $(1.11))$
\end{tabular}

$\begin{array}{ll}\text { ER-evolutionary term } & - \\ \text { ER-common descent } & 0.81^{* * *} \\ \text { ER - selection } & 0.65^{* * *} \\ \text { IR - need-based adaptation } & 0.53^{* * *} \\ \text { IR - desire-based change } & -0.09 \\ \text { IR - proximate cause } & -0.44^{* * *} \\ \text { CR-intentional design } & -0.51^{* * *}\end{array}$

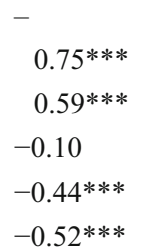

$\begin{array}{lc}- & \\ 0.66^{* * *} & - \\ -0.02 & 0.13 \\ -0.43 * * * & -0.26^{*} \\ -0.46^{* * *} & -0.21\end{array}$

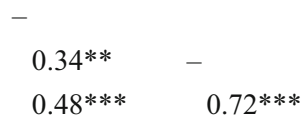

Pearson's $r$ used to calculate intercorrelations

$E R$ evolutionary reasoning, $I R$ intuitive reasoning, $C R$ creationist reasoning

${ }^{*} p<0.05 ; * * p<0.01 ; * * * p<0.001$

\section{General Discussion}

These findings demonstrate that a single visit to an interactive exhibition on evolution effects positive though incremental change in museum visitors' understanding of evolution, regardless of the beliefs, interests, or age of the visitor. Given the self-selection of the volunteer sample, this is an important finding. This study was undertaken to further our understanding of how an exhibition on evolution might influence visitors' reasoning. While museum visitors are more likely than the population at large to be highly educated and knowledgeable about science (Korn 1995), they still hold alternative conceptions, using intuitive and creationist reasoning to explain evolutionary change (Evans 2005, 2008; Macfadden et al. 2007). In keeping with our first research prediction, even though this sample of visitors increased their endorsement and expression of evolutionary ideas, they still maintained some aspects of the intuitive reasoning patterns that they held prior to the visit, albeit at lower levels of endorsement.

Evolution is a controversial topic that is misunderstood by many U.S. citizens. While it is unlikely that a single visit to a museum exhibition would elicit transformational changes in reasoning about this topic, incremental changes are critical steps along a visitor's educational journey. Although the overall change we measured in this study was incremental rather than transformational, this change did occur for over $90 \%$ of the visitors on the closed-ended questionnaire. Understanding the nature of these incremental changes can help us learn how to foster those skills that may lead to more radical change over time (Vosniadou 2008; Vosniadou et al. 2008), as well as how to foster such changes in populations who might be less interested in natural history, or ideologically opposed to evolutionary

Table 9 Intercorrelations between sociocultural, personal, and contextual variables and the closed-ended explanations from the three reasoning patterns

\begin{tabular}{|c|c|c|c|c|c|c|c|}
\hline $\begin{array}{l}\text { Sociocultural personal and contextual } \\
\text { variables }\end{array}$ & $\begin{array}{l}\text { ER } \\
\text { evolution } \\
\text { term }\end{array}$ & $\begin{array}{l}\text { ER } \\
\text { Selection }\end{array}$ & $\begin{array}{l}\text { ER common } \\
\text { descent }\end{array}$ & $\begin{array}{l}\text { IR need-based } \\
\text { adaptation }\end{array}$ & $\begin{array}{l}\text { IR desire- } \\
\text { based change }\end{array}$ & $\begin{array}{l}\text { IR proximate } \\
\text { cause }\end{array}$ & $\begin{array}{l}\text { CR intentional } \\
\text { design }\end{array}$ \\
\hline Religiosity & $-0.25^{*}$ & -0.18 & -0.23 & 0.01 & 0.00 & $0.28 *$ & 0.32 \\
\hline Compatibility of own religion with evolution & $0.34 * *$ & $0.38 * *$ & $0.39 * *$ & 0.22 & -0.23 & -0.13 & $-0.39 * *$ \\
\hline Acceptance of evolutionary origins & $0.87 * * *$ & $0.57 * * *$ & $0.74 * * *$ & $0.41 * * *$ & -0.11 & $-0.40 * *$ & $-0.52 * * *$ \\
\hline Importance of scientists' studying evolution & $0.34 * *$ & 0.24 & $0.34 * *$ & 0.17 & -0.31 & $-0.34 * *$ & $-0.37 * *$ \\
\hline Importance of self understanding evolution & $0.51 * * *$ & $0.37 * *$ & $0.52 * * *$ & 0.24 & $-0.28^{*}$ & $-0.43 * * *$ & $-0.56 * * *$ \\
\hline Own knowledge of evolution & $0.36^{* *}$ & 0.24 & 0.19 & $0.27 *$ & -0.06 & -0.19 & $-0.28^{*}$ \\
\hline Time spent at exhibit & 0.24 & 0.18 & 0.11 & 0.11 & -0.15 & $-0.33 * *$ & $-0.32 * *$ \\
\hline Interest in the organisms in the exhibit & $0.51 * * *$ & $0.41 * * *$ & $0.47 * * *$ & 0.23 & -0.03 & -0.07 & $-0.30^{*}$ \\
\hline Age & 0.17 & 0.14 & 0.11 & 0.00 & -0.23 & -0.21 & $-0.33 * *$ \\
\hline
\end{tabular}

Pearson's $r$ was used for interval data comparisons, including summated scale scores; Spearman's rho was used for ordinal data comparisons $E R$ evolutionary reasoning, $I R$ intuitive reasoning, $C R$ creationist reasoning

$* p<0.05 ; * * p<0.01 ; * * * p<0.001$ 
ideas. We address the nature of those changes in the next sections. Moreover, we consider a further issue central to an understanding of informal and formal science learning: Why was the exhibition successful? We suggest that the critical component was the nature of the exhibition itself, which included unique elements that contributed to the learning of a difficult and controversial topic. Additionally, our measures were constructed to be sensitive to a fine-grained analysis of explanation change.

\section{What Changed? Utilizing Multiple Explanatory Systems}

The exhibition was effective in enabling visitors to use evolutionary reasoning more frequently to explain evolutionary problems for all organisms as measured in the openand closed-ended items. Yet the intuitive reasoning patterns were not necessarily supplanted. Consistent with our second research prediction, need-based reasoning was disassociated from the other two types of intuitive reasoning explanations. In contrast with previous research, our closed-ended instrument made it possible for visitors to endorse each explanation independently of the others, permitting a more nuanced analysis of their relationships and providing evidence for this claim. We found that in contrast with the other two intuitive explanations assessed, endorsement of need-based reasoning increased substantially following the gallery visit; moreover, and again unlike desire-based (want) and proximate cause reasoning, need-based reasoning was correlated positively with evolutionary reasoning. On the other hand, endorsement of desire-based and proximate cause explanations and the (creationist) intentional design explanation decreased following the visit, and all three of them were positively correlated. Furthermore, need-based reasoning was uncorrelated with desire-based reasoning and negatively correlated with proximate-cause reasoning. These patterns provide some evidence that these intuitive explanations may be embedded in different frameworks, with desire-based and proximate cause reasoning more closely aligned with an intentional framework and need-based reasoning more closely aligned with a naïve biological framework (Evans 2008).

Overall though, adults, in contrast to the younger visitors, seemed better able to integrate information from the exhibition and reject intuitive explanations. Visitors' responses to the open-ended questions were consistent with the pattern of closed-ended endorsements, demonstrating that a large proportion of all visitors continued to use intuitive explanations to explain evolutionary change, although this was particularly the case for the youngest visitors.

One possible explanation for these findings is the language used in the exhibition itself. An exhibition on evolution serves as a translation between the language of evolutionary biologists and the everyday language of the lay person. Prior studies on museum visitors' explanations of evolution had demonstrated that need-based reasoning was as much of a problem for museum visitors (Evans et al. 2010; Macfadden et al. 2007) as it was for high-school and college students (e.g., Banet and Ayuso 2003; Bishop and Anderson 1990) and teachers (Nehm et al. 2010a). Although adult museum visitors rarely use desire-based reasoning to explain evolutionary change, it is often used by younger elementary school children (Evans 2000; Legare et al. 2012). Consequently, the exhibition developers strove to eliminate any intuitive language from the explanatory labels; even so, adult visitors not only continued to use need-based language but increased their use following the gallery visit. The positive correlations between need-based reasoning and evolutionary explanation support an alternative hypothesis, suggested earlier, that the use of need-based reasoning serves as stepping stone from the intuitive reasoning pattern to an evolutionary reasoning pattern.

Despite much criticism, evolutionary biologists regularly talk of evolutionary design and often pepper their language with teleological explanations (e.g., Jungwirth 1975; Sprinkle 2006). Indeed, for Darwin the language of design was part and parcel of his intellectual history (Beer 2000). But importantly for biologists, as it was for the visitors following the gallery visit, need-based reasoning is likely to be disassociated from the anthropomorphic or mentalistic language of wants or desires (see Mayr 1982, pp. 48-49). Even young elementary school children can distinguish between desires and needs in that they realize that humans do not breathe because they want to, but because they need to (Poling and Evans 2002). What appeared to be happening during the visit to "Explore Evolution" is that visitors' need-based explanations for the evolution scenarios became disassociated from the desire-based explanations and increasingly associated with evolutionary mechanisms of change.

These results provide support for the suggestion that the "taboo against anthropomorphic and teleological language" be removed (Zohar and Ginossar 1998). Zohar and Ginossar found that high school students were cognizant of the difference between the use of such language in a metaphorical sense as a general heuristic to help them understand evolutionary explanations and its use as a causal explanation. Our study suggests a further refinement. Students or members of the public should be made aware of the difference between anthropomorphic (desire-based) and need-based language and encouraged to use the latter rather than the former. Once they realize that a particular adaptation is needed because it is necessary for survival and, moreover, that the organism cannot make a conscious decision to acquire that adaptation, this lays a foundation for understanding the mechanisms that underlie evolutionary change.

Incremental changes in visitors' reasoning are small steps that may eventually yield a major restructuring in the underlying reasoning patterns. Child and adult visitors in this 
study accessed multiple explanatory systems to explain biological events; moreover, they shifted between explanatory frameworks as a consequence of the gallery visit. Based on the conceptual framework used in this study (Evans 2005), Nehm et al. (2010a) also found similar patterns of mixed reasoning in biology and non-biology teachers' explanations, indicating that such patterns are widespread. The intentional mode, part of an everyday folk psychology, clearly does not disappear as a consequence of a museum visit or courses in evolutionary biology. Instead, what appears to be happening is that the learner realizes that it is inappropriate to apply this kind of explanation to an evolutionary scenario. Over the course of the gallery visit, visitors were fine-tuning their explanatory repertoire.

\section{Why Was the "Explore Evolution" Exhibition Successful?}

What unique aspects of the "Explore Evolution" exhibition may have fostered these changes? In contrast to many natural history exhibitions (Diamond and Scotchmoor 2006), "Explore Evolution" explained natural selection using a cognitive organizer, the VIST acronym, which has been used with success on the University of California Museum of Paleontology website as an educational tool. The repetition of the VIST elements across seven different exhibits allowed visitors to generalize their understanding of evolution principles across multiple organisms. In data gathered from a similar sample of natural history museum visitors prior to the installation of the exhibition (Evans et al. 2010), one of the more interesting findings was that visitors did not spontaneously apply evolutionary explanations across a range of organisms; they were much more likely to apply them to birds and mammals than to the other species. This exhibition improved visitors' ability to generalize across diverse living kinds.

Another issue highlighted in the earlier study was that although many of the visitors accepted evolutionary ideas, they did not use evolutionary mechanisms to explain change. Again, there was a significant shift among the current visitors. Not only did they endorse natural selection explanations in the closed-ended questions, they also used them to explain the open-ended evolutionary scenarios and, moreover, included sexual selection (not one visitor mentioned sexual selection in the earlier study, Evans et al. 2010). The use of multiple representations of the same elements, along with appropriate labeling, has been shown to enhance visitor understanding (Botelho and Morais 2006; Falk and Dierking 2000), and this appears to have been a contributing factor to success here as well.

A further explanation for this exhibition's success is that, in contrast to more traditional natural history exhibitions, "Explore Evolution" presented contemporary research on evolution. Each exhibit portrayed present-day scientists carrying out their work in the laboratory or in the field, depending on their area of expertise. The evidence supporting each particular investigation was found in each exhibit, often in an interactive mode; moreover, fossil evidence was tied to genetic evidence. There were multiple representations of the nature of scientific investigations, making any argument about the falsification of all this evidence much less credible. We propose that this presentation of the evidence for evolution was believable even to those who were not initially prepared to endorse evolutionary ideas.

Sociocultural Factors Our measurement of visitors' reasoning patterns began with a detailed conceptual model derived from earlier work (Evans 2001, 2008; Evans et al. 2010) and was used with success in the current study to model incremental - not radical — conceptual change (Carey 1985; Vosniadou 2008). Without that foundation, we would not have been able to measure or even anticipate the changes that were likely to occur. Note that in this model we assessed whether visitors' causal explanations for biological scenarios changed. We did not assess whether they had acquired new facts about the particular organisms in the exhibition. At the same time, we embedded this model in a free-choice learning framework (Falk and Dierking 2000) and included measures of context or engagement as well as measures of visitors' sociocultural affiliations. As predicted, these variables were significantly related to the knowledge structure underlying visitors' explanations of evolutionary change.

Providing evidence against our third prediction, however, we found that visitors who initially endorsed the creationist intentional design explanation changed as much, if not more (because they had more room to change), than visitors who were already sympathetic to evolutionary ideas. Of course, as volunteers, they may not have been as ideologically opposed to evolutionary ideas as creationists in the population at large. Only those who hold a literal interpretation of the Bible are likely to find the theory of evolution untenable. Indeed, in our sample, religiosity per se was virtually unrelated to visitors' endorsement of different explanations. On the other hand, the compatibility of a visitor's religion with evolutionary theory was strongly related. Visitors who endorsed the compatibility measure at higher levels were more likely to endorse evolutionary explanations, accept the idea of evolutionary origins, think it is important for scientists to study evolution, think it is important for oneself to understand evolution, and to find the organisms in the exhibition interesting. Conversely, visitors who believed their religious convictions were incompatible with evolution were more likely to endorse the creationist explanation and less likely to endorse evolutionary explanations. However, as just described, even these visitors increased their endorsement of evolution following the visit. 
The effects measured here reflect learning immediately following the museum visit, while longer-lasting effects would need to be assessed in the months following this visit. Additionally, the post-test scenarios presented to the visitors were similar to those seen in the exhibition. Measurement of retention and transfer would be an important contribution to future studies of this nature.

Developmental Factors The greater use of intuitive reasoning in children was consistent with our fourth prediction, and it suggests that children may benefit from having an accompanying adult to help interpret the VIST framework as they visit the exhibition. Crowley et al. (2001) found that children spend more time at museum exhibits when they are with their parents. Parents provide information about causal mechanisms and help children to build "islands of expertise" by bridging past experiences with new exhibit information (Crowley and Jacobs 2002). This highlights one limitation of this study, which is that all except two of our visitors saw the exhibition alone. Visitor engagement and learning is likely to be enhanced when the visit is a group event (Allen 2004; Falk and Dierking 2000). A recent study examining parent-child conversation at the same exhibition demonstrated that parents and children engaged in a rich dialogue in which $63 \%$ of the conversation was explanatory, with parents often reformulating exhibit text to make it more understandable for their children (Tare et al. 2011).

\section{Conclusion: Implications for Formal and Informal Learning Experiences}

This study demonstrates that museum exhibitions can contribute to the public's understanding of evolution. Whatever their age and background beliefs, the visitors in our sample learned more about evolutionary concepts in a single visit to an evolution exhibition. One important question that remains is whether these findings can be extended to informal and formal learning experiences for a broader spectrum of the public.

The differences between the somewhat more positive results we find in this study and the findings reported from semester-long courses in schools and colleges can be explained in several ways. Importantly, our criteria for success were modest. Therefore, in contrast to interventions in more formal settings (e.g., Bishop and Anderson 1990; Banet and Ayuso 2003; Passmore and Stewart 2002), we asked whether incremental change had occurred, not whether visitors could explain natural selection without the use of intuitive terminology. It is also important to note that consistent with research in formal settings, we did not find that visitors had abandoned their intuitive explanations, just that they were less likely to endorse anthropomorphic reasoning, and more likely to endorse need-based explanations as well as evolutionary explanations. Nor did we investigate change in a broad range of misconceptions; recent studies by Nehm et al., for example, have identified "force-talk" as a compelling intuitive explanation (Nehm et al. 2010b). In terms of the public understanding of science, however, our modest expectations are more realistic (Falk et al. 2007). Additionally, our instruments were developed in a two-stage process and were very sensitive to subtle changes in explanatory structure because, unlike open-ended instruments, they allowed visitors to endorse each type of explanation independently of the others.

From the perspective of conceptual change theory (Sinatra et al. 2008), one issue this study highlights is that the use of multiple explanatory systems is normative (Evans 2005; Evans et al. 2011; Nehm et al. 2010a). Visitors shifted effortlessly between evolutionary, intuitive, and creationist explanations as the circumstances dictated, often endorsing multiple explanations concurrently. These findings imply that conceptual change may often be achieved by fine-tuning a particular explanatory system, rather than supplanting intuitive or creationist explanations with evolutionary ones. This is an important finding. It suggests that the task of teaching evolution should not necessarily be viewed as a struggle to identify and supplant intuitive misconceptions (e.g., Gregory 2009). Rather it is more of an organic process in which evolutionary explanations emerge out of earlier intuitive ideas, especially need-based explanations; however, the latter are maintained but used in a more restricted manner than before.

This suggestion, that need-based reasoning may represent a transition point rather than a misconception, challenges the current consensus that it is an impediment to learning (e.g., Bishop and Anderson 1990; Nehm et al. 2010a; Nehm and Schonfeld 2008; Southerland et al. 2001). Our argument, however, is simply that not all forms of teleological reasoning are equally problematic. The realization that out of necessity an organism needs to change to survive in a particular environment and that this change cannot be achieved intentionally is an important step, we propose, in a learning progression (e.g., Duncan and Hmelo-Silver 2009) from intuitive to evolutionary reasoning (Evans et al. 2012). Moreover, the changes we observed in visitors' reasoning are consistent with both historical (Mayr 1982; Quammen 2006) and ontogenetic patterns of change (Evans 2000; Legare et al. 2012).

Our goal in the current study was to discover whether measurable learning can occur in a single museum visit. It does. Nevertheless, future research should verify whether this learning is retained and whether this kind of exposure can jump start students' understanding. For museum visitors and students who do not realize that evolutionary principles apply to all living things, even a short immersion in an experience such as "Explore Evolution" could be a crucial 
step toward convincing them otherwise. Presenting contemporary evidence for evolution across diverse organisms, from the virus to the whale, seems to be an effective way of educating the public that evolutionary concepts apply to all living organisms.

Acknowledgments We gratefully acknowledge data collection by Karen Johnson, Sarah Thompson, and Hilary Kindschuh. We would also like to thank museum directors and their staff, Ellen Censky from the Sam Noble Oklahoma Museum of Natural History, Priscilla Grew from the University of Nebraska State Museum, Amy Harris from the University of Michigan Exhibit Museum of Natural History, Edward Theriot from the Texas Natural Science center, and Leonard Krishtalka from the University of Kansas Natural History Museum and Biodiversity Center. Special thanks go to Katrina Hase, Rob Sharot, and Paul Martin from the Science Museum of Minnesota for guiding the creation of the "Explore Evolution" exhibit. We gratefully acknowledge the assistance of John Klausmeyer from the Exhibits Museum of Natural History, and Angie Fox from the University of Nebraska State Museum. This material is based upon work supported by the National Science Foundation under grants no. 0229294 (Diamond) and no. 0411406 (Evans).

\section{Appendix A}

\section{Biological change questions used in closed-ended instrument}

Fruit flies: At one time there were no fruit flies on the Hawaiian Islands. Scientists think that several million years ago, a few fruit flies came to the islands. Now there are more than 800 different kinds of fruit flies throughout Hawaii. How would you explain these observations?

Finches: One year, scientists measured the beaks of one kind of finch on a remote island. They found that most of these finches had small beaks. The next year, a drought wiped out most of the plants that produced small seeds, but the plants that made large seeds remained. A few years later, when scientists measured the finches' beaks again, they found more finches with big beaks. How would you explain these observations?

Diatoms: Scientists have found a kind of diatom (onecelled algae) in Yellowstone Lake that is not found anywhere else in the world. When the climate started to warm thousands of years ago, this kind of diatom began to appear in the fossil record. Today, this kind of diatom is common in the lake. How would you explain these observations?

HIV virus: George is a patient who has a virus called HIV. When scientists first examined George, they found he had three types of HIV, each slightly different. Later when George went back for a check-up, he had five types of HIV. How would you explain these observations?

Ants and fungus: A kind of ant grows a type of fungus for food. There is a pest that attacks this fungus. These ants carry bacteria that protect the fungus from this pest. How would you explain these observations?
Whales: Scientists have discovered a fossil whale that has legs for walking and nostrils for swimming. The ankle bones of this fossil whale are similar to the ankle bones of modern hippos. How would you explain these observations?

Humans and chimps: Scientists have discovered that over $98 \%$ of human and chimp DNA is identical. Modern chimps and humans are similar in many ways, but different in other ways. How would you explain these observations?

\section{References}

Adelman LM, Falk J, James S. Impact of national aquarium in Baltimore on visitors' conservation attitudes, behavior, and knowledge. Curator. 2000;43(1):33-61.

Allen S. Designs for learning: studying science museum exhibits that do more than entertain. Sci Educ. 2004;88 Suppl 1:S17-33.

American Association for the Advancement of Science. Benchmarks for science literacy. New York: Oxford University Press; 1994.

Anderson D, Lucas KB, Ginns IS, Dierking LD. Development of knowledge about electricity and magnetism during a visit to a science museum and related post-visit activities. Sci Educ. 2000;84(5):658-79.

Bamberger Y, Tal T. Learning in a personal context: levels of choice in a free choice learning environment in science and natural history museums. Sci Educ. 2007;91(1):75-95.

Banet E, Ayuso GE. Teaching of biological inheritance and evolution of living beings in secondary school. Int J Sci Educ. 2003;25:273407.

Beer G. Darwin's plots: evolutionary narrative in Darwin, George Eliot and nineteenth-century fiction. Cambridge: Cambridge University Press; 2000.

Bell P, Lewenstein B, Shouse AW, Feder MA, editors. Learning science in informal environments: people, places, and pursuits. Committee on Learning Science in Informal Environments, National Research Council. Washington: NAS Press; 2009.

Bishop BA, Anderson CW. Student conceptions of natural selection and its role in evolution. J Res Sci Teach. 1990;27:415-28.

Bloom P, Weisberg DS. Childhood origins of adult resistance to science. Science. 2007;316:996-7.

Borun M. Being human: a design in process, four focus groups. University of Pennsylvania Museum: Museum Solutions; 2002.

Botelho A, Morais AM. Students-exhibits interaction at a science center. J Res Sci Teach. 2006;43:987-1018.

Brumby M. Problems in learning the concept of natural selection. J Biol Educ. 1979;13:119-22.

Bybee RW. Achieving scientific literacy: strategies for insuring that free-choice science education complements national formal science education efforts. In: Falk JH, editor. Free-choice science education: how we learn science outside of school. New York: Teachers College Press; 2001. p. 44-63.

Carey S. Conceptual change in childhood. Cambridge: MIT Press; 1985.

Catley KM. Darwin's missing link - a novel paradigm for evolution education. Sci Educ. 2006;90:767-83.

Crowley K, Jacobs M. Building islands of expertise in everyday family activity. In: Leinhardt G, Crowley K, Knutson K, editors. Learning conversations in museums. Mahwah: Lawrence Erlbaum Associates, Inc; 2002.

Crowley K, Callanan MA, Jipson JL, Galco J, Topping K, Shrager J. Shared scientific thinking in everyday parent-child activity. Sci Educ. 2001;85:712. 
D'Elia G, Jörgensen C. National survey of the markets for museums, public libraries, public television, public radio, and their engagement in informal learning activities. Report submitted to the Urban Libraries Council. Buffalo: State University of New York, School of Informatics; 2003.

Diamond J, Evans EM. Museums teach evolution. Evolution. 2007;61 (6):1500-6.

Diamond J, Evans EM, Spiegel A. Walking whales and singing flies: an evolution exhibit and assessment of its impact. In: Rosengren, KR, Brem, S, Evans, EM, Sinatra, G, editors. Evolution challenges: integrating research and practice in teaching and learning about evolution. London: Oxford University Press; 2012. p. 587-614.

Diamond J, Scotchmoor J. Exhibiting evolution. Mus Soc Issues. 2006;1(1):21-48.

Duncan RG, Hmelo-Silver CE. Editorial: learning progressions: aligning curriculum, instruction, and assessment. J Res Sci Teach. 2009;46:606-9.

Evans EM. The emergence of beliefs about the origins of species in school-age children. Merrill-Palmer Q J Dev Psychol. 2000;46:22154.

Evans EM. Cognitive and contextual factors in the emergence of diverse belief systems: Creation versus evolution. Cogn Psychol. 2001;42:217-66.

Evans EM. Teaching and learning about evolution. In: Diamond J, editor. The virus and the whale: explore evolution in creatures small and large. Arlington: NSTA Press; 2005. p. 25-41.

Evans EM. Conceptual change and evolutionary biology: a developmental analysis. In: Vosniadou S, editor. International handbook of research on conceptual change. New York: Routledge; 2008. p. 263-94.

Evans EM, Spiegel AN, Tare M, Frazier BF, Cover S, Gram W, et al. A conceptual guide to natural history museum visitors' understanding of evolution. J Res Sci Teach. 2010;47(3):326-53.

Evans EM, Legare C, Rosengren K. Engaging multiple epistemologies: implications for science education. In: Ferrari M, Taylor R, editors. Epistemology and science education: understanding the evolution vs. intelligent design controversy. New York: Routledge; 2011. p. $111-39$.

Evans EM, Rosengren K, Lane JD, Price KS. Encountering counterintuitive ideas: constructing a developmental learning progression for biological evolution. In Rosengren KR, Brem S, Evans EM, Sinatra G, editors. Evolution challenges: integrating research and practice in teaching and learning about evolution. London: Oxford University Press; 2012

Falk JH, Adelman LM. Investigating the impact of prior knowledge and interest on aquarium visitor learning. J Res Sci Teach. 2003;40(2):163-76.

Falk JH, Dierking LD. Learning from museums: visitor experiences and the making of meaning. Walnut Creek: Alta Mira Press; 2000.

Falk JH, Dierking LD. Lessons without limit: how free-choice learning is transforming education. Walnut Creek: Alta Mira Press; 2002.

Falk J, Storksdieck M. Using the contextual model of learning to understand visitor learning from a science center exhibition. Sci Educ. 2005;89(5):744-78.

Falk JH, Storksdieck M, Dierking LD. Investigating public science interest and understanding: evidence for the importance of freechoice learning. Public Underst Sci. 2007;16:455-69.

Gelman SA. The essential child: origins of essentialism in everyday thought. Oxford: Oxford University Press; 2003.

Greene ED. The logic of university students' misunderstanding of natural selection. J Res Sci Teach. 1990;27:875-85.

Gregory TR. Understanding natural selection: essential concepts and common misconceptions. Evol Educ Outreach. 2009;2:156-75.

Hayward J, Hart J, Gyllenhaal E. Summative evaluation of the "Life Over Time" exhibit at the Field Museum. Northampton: People, Places, and Design Research; 1996.
Jiménez-Aleixandre MP. Teaching evolution and natural selection: a look at textbooks and teachers. J Res Sci Teach. 1994;31:519-35.

Jungwirth E. Preconceived adaptation and inverted evolution: a case of distorted concept formation in high school biology. Aust Sci Teach J. 1975;21:95-100.

Keil FC. The birth and nurturance of concepts by domains: the origins of concepts of living things. In: Hirschfeld LA, Gelman SA, editors. Mapping the mind: domain specificity in cognition and culture. Cambridge: Cambridge University Press; 1994. p. 234-54.

Kelemen D. The scope of teleological thinking in preschool children. Cognition. 1999;70:241-72.

Korn R. An analysis of differences between visitors at natural history museums and science centers. Curator. 1995;38(3):150-60.

Legare C, Lane J, Evans EM. Anthropomorphizing science: How does it affect the development of evolutionary concepts? MerrillPalmer Q J Dev Psychol. 2012; (in press)

Lerner LS. Good science, bad science: teaching evolution in the states. Washington, DC: Thomas B. Fordham Foundation; 2000.

Macfadden BJ, Dunckel BA, Ellis S, Dierking LD, Abraham-Silver L, Kisiel J, et al. Natural history museum visitors' understanding of evolution. BioScience. 2007;57(10):875-82.

Mayr E. The growth of biological thought: diversity, evolution and inheritance. Cambridge: Harvard University Press; 1982.

Mazur A. Believers and disbelievers in evolution. Polit Life Sci. 2005;8:55-61.

Medin DL, Atran S. The native mind: biological categorization and reasoning in development and across cultures. Psychol Rev. 2004;111(4):9960-83.

Miller JD. The acquisition and retention of scientific information by American adults. In: Falk JH, editor. Free-choice science education: how we learn science outside of school. New York: Teachers College Press; 2001. p. 93-114.

Moore R, Kraemer K. The teaching of evolution \& creationism in Minnesota. Am Biol Teach. 2005;67(8):457-66.

National Research Council. National science education standards. Washington, DC: National Academy Press; 1996.

National Science Board. Science and Engineering Indicators 2012. Arlington: National Science Foundation (NSB-1201); 2012.

Nehm RH, Schonfeld IS. Measuring knowledge of natural selection: a comparison of the CINS, an open-ended instrument, and an oral interview. J Res Sci Teach. 2008;45(10):1131-60.

Nehm RH, Kim SY, Sheppard K. Academic preparation in biology and advocacy for teaching evolution: biology versus non-biology teachers. Sci Educ. 2010a;93:1122-46. doi:10.1002/sce.20340.

Nehm RH, Rector MA, Ha M. "Force-talk" in evolutionary explanation: metaphors and misconceptions. Evol Educ Outreach. 2010b;3:605-13.

Norman G. Likert scales, levels of measurement and the "laws" of statistics. Adv Health Sci Educ. 2010;15:625-32.

Numbers RL. The creationists: the evolution of scientific creationism. New York: Knopf; 1992.

Nunnally J. Psychometric theory. New York: McGraw-Hill; 1978.

Passmore C, Stewart J. A modeling approach to teaching evolutionary biology in high schools. J Res Sci Teach. 2002;39:185-204.

Pawlukiewicz JD, Doering Z, Paasch K. Views from the audience: planning a new exhibition on human evolution. Paper presented at the Current Trends in Audience Research and Evaluation Conference, Washington, DC.; 1990.

People for the American Way. Evolution and creationism in public education: an in-depth reading of public opinion: results of a comprehensive, national survey. Washington, DC: People for the American Way; 2000.

People, Places, and Design Research. Life over time, formative evaluation study \#3: visitors' understanding of scientific terms. Northampton: People, Places and Design Research; 1992. 
Poling DA, Evans EM. Why do birds of a feather flock together? Developmental change in the use of multiple explanations: intention, teleology, essentialism. Br J Dev Psychol. 2002;20:89-112.

Quammen D. The reluctant Mr. Darwin. New York: Norton; 2006.

Ramey-Gassert L, Walberg III HJ, Walberg HJ. Reexamining connections: museums as science learning environments. Sci Educ. 1994;78(4):345.

Rutledge ML, Mitchell MA. High school biology teachers' knowledge structure, acceptance and teaching of evolution. Am Biol Teach. 2002;64(1):21-8.

Sinatra GM, Brem SK, Evans EM. Changing minds? Implications of conceptual change for teaching and learning about biological evolution. Evol Educ Outreach. 2008;1:189-95.

Smithsonian Institution. Eaters of the Smithsonian sun: characteristics of visitors to Smithsonian museums. Washington, DC: Smithsonian Institution, Office of Policy and Analysis; 2006.

Smithsonian Institution. Nature, science and culture on display: results from the 2009-2010 National Museum of Natural History Visitor Survey. Washington, DC: Smithsonian Institution, Office of Policy and Analysis; 2010.

Southerland SA, Abrams E, Cummins CL, Anzelmo J. Understanding students' explanations of biological phenomena: conceptual frameworks or P-Prims. Sci Educ. 2001;85:328-48.

Spiegel AN, Evans EM, Gram W, Diamond J. Museum visitors understanding of evolution. Mus Soc Issues. 2006;1(1):69-86.

Sprinkle RH. Unremembered intimacies. Review of "beasts of the earth: animals, humans, and disease" by E. F. Torrey and R. H. Yolken. BioScience. 2006;56:166-7.

Squire J, Hubbell Mackinney L. Learning from Lucy: What visitors want to know about human evolution. An evaluation study of the Lucy skeleton in the "Creatures of the Ice Age" exhibit at the
California Academy of Sciences. San Francisco: California Academy of Sciences; 1996.

St. John M, Perry D. A framework for evaluation and research: science, infrastructure and relationships. In: Bicknell S, Farmelo G, editors. Museum visitor studies in the 90's. London: Science Museum; 1993. p. 59-66.

Stein JK, Storksdieck M. Life changes museum visitor survey: summary of results. Annapolis: Institute for Learning Innovation; 2005.

Tare M, French J, Frazier B, Diamond J, Evans EM. Explanatory parent-child conversation predominates at an evolution exhibit. Sci Educ. 2011;95:720-44. doi:10.1002/sce.20433.

Trowbridge JE, Wandersee JH. Identifying critical junctures in learning in a college course on evolution. J Res Sci Teach. 1994;31:45973.

Vadeboncoeur JA. Chapter 7: engaging young people: learning in informal contexts. Rev Res Educ. 2006;30(1):239-78.

Vosniadou S. Conceptual change research: an introduction. In: Vosniadou $\mathrm{S}$, editor. International handbook of research on conceptual change. New York: Routledge; 2008. p. xiii-xxviii.

Vosniadou S, Vamvakoussi X, Skopeliti I. The framework theory approach to the problem of conceptual change. In: Vosniadou S, editor. International handbook of research on conceptual change. New York: Routledge; 2008. p. 3-34.

Wellman HM, Gelman SA. Knowledge acquisition in foundational domains. In: Damon W, Kuhn D, Siegler R, editors. Handbook of child psychology: vol. 2. Cognition, perception and language. 5th ed. New York: Wiley; 1998. p. 523-74.

Zohar A, Ginossar S. Lifting the taboo regarding teleology and anthropomorphism in biology education-heretical suggestions. Sci Educ. 1998;82:679-97. 